\title{
Analisis Struktur Penyajian Kesenian Dogdog Kuda Lumping Panggeuing Ati Group Di Citapen Kidul Kota Tasikmalaya
}

\author{
Ikhsan Tri Julian \\ Prodi Sendratasik Fakultas Keguruan dan Ilmu pendidikan, Universitas Muhammadiyah Tasikmalaya \\ Jl. Tamansari No. KM 2.5 Mulyasari Kec. Tamansari Tasikmalaya Jawa Barat \\ Email: Ikhsan.tasik2015@gmail.com
}

\begin{abstract}
ABSTRAK
Penelitian ini bertujuan untuk menganalisis struktur penyajian kesenian Dogdog Kuda Lumping Panggeuing Ati Group di Citapen Kidul Kota Tasikmalaya. Objek penelitian ini adalah pemimpin kesenian Dogdog Kuda Lumping Panggeuing Ati Group di Citapen Kidul Kota Tasikmalaya. Penelitian ini difokuskan pada Analisis Struktur Penyajian Kesenian Dogdog Kuda Lumping. Penelitian ini menggunakan pendekatan Kualitatif Deskriptif. Lokasi penelitian dilakukan di Citapen Kidul Kota Tasikmalaya. Objek dalam penelitian ini adalah kesenian Dogdog Kuda Lumping Panggeuing Ati. Data diperoleh melalui observasi langsung di padepokan kuda lumping panggeuing ati. Wawancara dilakukan dengan pememimpin kuda lumping panggeuing ati, serta dokumentasi yang berupa foto dan rekaman wawanacara. Hasil temuan penelitian ini menunjukan bahwa, terdapat beberapa perbedaan dalam struktur penyajian kesenian dogdog kuda lumping panggeuing ati, dengan kesenian kuda lumping pada umumnya. Hal tersebut dilihat dari struktur gerak, struktur musik, tata rias dan busana, dan properti yang digunakan dalam penyajiannya. Tahapan penyajian Dogdog Kuda Lumping dengan Kuda Lumping pada umumnya berbeda dari pola iringan dan pola gerakannya.

Kata kunci: analisis, struktur penyajian kesenian, dogdog kuda lumping.
\end{abstract}

\section{ABSTRACT}

This study aims to analyze the presentation of the art of Dogdog Kuda Lumping Panggeuing Ati Group in Citapen Kidul, Tasikmalaya City. The object of this research is the art leaders of Dogdog Kuda Lumping Panggeuing Ati Group in Citapen Kidul, Tasikmalaya City. This research is about Analysis of the Art Presentation Structure of Kuda Lump Dogdog. This research use desciptive qualitative approach. The research location was conducted in Citapen Kidul, Tasikmalaya City. The object of this research is the Art of Dogdog Kuda Lumping Panggeuing Ati. Data were obtained through direct observation at the Kuda Lumping Panggeuing Ati hermitage. Interviews were conducted with the leader of Kuda Lumping Panggeuing Ati, as well as documentation in the form of photos and recorded interviews. The findings of this study indicate that, there are several differences in the presentation of the art of Kuda Lumping ati dogdog, with the art of Kuda Lumping in general. This can be seen from the structure of the movement, the structure of the music, make-up and clothing, and the properties used in the presentation. The stages of presenting the Kuda Lumping Dogdog with the Kuda Lumping are generally different from the accompaniment and movement patterns.

Keywords: analysis, serving, dogdog Kuda Lumping

\section{A. Pendahuluan}

Kebudayaan merupakan hasil cipta dan karsa manusia, dan merupakan suatu kekayaan yang sampai saat ini masih kita miliki dan tentu saja harus kita pelihara. Tiap masyarakat mempunyai kebudayaan yang berbeda dengan kebudayaan masyarakat lainnya, ragam budaya inilah yang menjadi bukti bahwa bangsa kita kaya akan kebudayaan.

Akan tetapi seperti yang di ungkapkan Koentjaraningrat (1997:13) bahwa menurutnya, kebudayaan adalah segala pikiran dan perilaku manusia yang secara fungsional dan disfungsional ditata dalam masyarakatnya.

Koentjaraningrat (dalam Kusumohamidjojo, 2001a:72) juga menegaskan bahwa menurut antropologi, "kebudayaan adalah seluruh sistem gagasan dan rasa, tindakan, serta karya yang dihasilkan manusia dalam kehidupan bermasyarakat, yang dijadikan miliknya dengan belajar."

Secara etimologi, Haviland (1985:229) mengartikan, "kesenian berasal dari kata dasar seni (art) yang berarti penggunaan imajinasi dan 
kreatifitas manusia dalam menerangkan, memahami, dan menikmati kehidupan".

Djohan, (2009:88) menerangkan bahwa musik digunakan dalam permainan dan tarian, mengorganisir kerja dan perang, upacara dan ritual, penanda kelahiran, perkawinan, dan kematian, merayakan panen dan penobatan, meneguhkan kepercayaan dan kegiatan tradisi.

Di Jawa Barat pada era modern seperti ini, seni dan budaya tradisional sering kali menjadi topik yang terlupakan di kalangan masyarakat Indonesia.

Akibatnya, tidak sedikit kesenian dan kebudayaan Indonesia yang diklaim oleh bangsa lain sebagai milik bangsanya sendiri. Padahal seni dan budaya merupakan sebuah warisan dan kekayaan bangsa Indonesia yang seharusnya dipertahankan dan diwariskan dari generasi ke generasi sebagai identitas bangsa.

Berbagai macam kesenian berkembang di Jawa Barat diantaranya, seni pertunjukan Wayang Golek, Jaipongan, tarian Ketuk Tilu, seni bela diri Pencak Silat, dan lain-lain. Sebagai seni pertunjukan rakyat kesenian tersebut juga didukung oleh alat musik tradisional Jawa Barat yang seperti, Gamelan, Rebab, Kendang, Terompet, Kecapi, Suling, dan lain sebagainya.

Kesenian-kesenian tradisional yang pada awalnya merupakan bagian dari sebuah ritual atau upacara adat, telah banyak beralih fungsi menjadi seni pertunjukan yang lebih mementingkan hiburan dan komersil tetapi tidak menghilangkan unsur-unsur atau nilainilai tradisi yang ada sebelumnya.

Kuda lumping merupakan salah satu jenis kesenian tradisional yang sangat populer sehingga dapat dikatakan bahwa hampir semua orang Jawa khususnya, dan Indonesia pada umumnya mengenal tarian ini. Tarian kuda lumping hingga kini masih tumbuh di banyak kelompok masyarakat khususnya di pulau Jawa.

Kuda lumping adalah seni tari yang dimainkan dengan meniki kuda tiruan dari anyaman bambu (kepang). Dalam memainkan seni ini biasanya juga diiringi dengan musik khusus yang sederhana karena hanya permainan rakyat, yaitu dengan Gong, Kenong, Kendang, dan Slompret, alat musik tradisional yang kini tidak lagi oleh anak-anak generasi muda karena telah tergantikan oleh drum, gitar, dan lainnya.

Difokuskan pada penelitian kali ini penulis membahas kesenian yang ada di Kota Tasikmalaya Adapun kesenian tersebut diberi nama kesenian "Dogdog Kuda Lumping Panggeuing Ati Group". Beralamat di Citapen Kidul Kelurahan Empangsari Kecamatan Tawang Kota Tasikmalaya.

Dulunya kesenian ini adalah kesenian Angklung Badud yang berdiri sejak tahun 1920 didirikan oleh Alm. Abah Aleh dengan beranggotakan keluarganya sendiri, lalu berkolaborasi dengan Alm. Aki Amir yang memiliki ilmu seni Debus sehingga sejak tahun 1950 menjadi kesenian Dogdog Kuda Lumping.

Sebagai wujud pelestarian kesenian Dogdog Kuda Lumping pemerintah Kota Tasikmalaya seringkali mengundang kelompok kesenian ini dalam berbagai acara besar di Tasikmalaya, agar kesenian tersebut tidak hilang seiring perkembangan zaman.

\section{B. Metode Penelitian}

Berdasarkan judul kajian dalam penelitian ini, peneliti menggunakan jenis penelitian deskripsi analisis dengan paradigma kualitatif. Menurut Bodgan dan Taylor (Moleong, 2012:4) penelitian kualitatif adalah produser penelitian yang menghasilkan data deskriptif berupa kata-kata tertulis atau lisan dari orangorang dan perilaku yang diamati. 
Dalam penelitian kualitatif seperti yang dikemukakan, rumusan masalah yang merupakan fokus penelitian masih bersifat sementara dan akan berkembang setelah peneliti masuk lapangan atau situasi sosial tertentu. Namun demikian setiap peneliti baik peneliti kuantitatif maupun kualitatif harus membuat rumusan masalah. Pertanyaan penelitian kualitatif dirumuskan dengan maksud untuk memahami gejala yang kompleks dalam kaitannya dengan aspek- aspek lain (in context).

Peneliti yang menggunakan pendekatan kualitatif, pada tahap awal penelitiannya, kemungkinan belum memiliki gambaran yang jelas tentang aspek-aspek masalah yang akan ditelitinya. la akan mengembangkan fokus penelitian sambil mengumpulkan data. Proses seperti ini disebut "emergent design" (Licoln dan Guba, 195:102).

\section{Hasil Penelitian}

1. Struktur Penyajian Dogdog Kuda Lumping Panggeuing Ati

Dalam setiap pementasan dogdog kuda lumping ini yang berbeda dengan pertunjukan kuda lumping pada umumnya. Didalam penyajiannya terdapat alat musik empat buah perkusi. Alat musik yang digunakan oleh kesenian dogdog kuda lumping ini adalah alat musik perkusi yang bernama Dogdog. Alat musik ini biasanya indentik dengan kesenian reak atau reog.

Selain daripada itu dalam setiap pementasan dogdog kuda lumping panggeuing ati ada salah satu bagian yang memperlihatkan suatu atraksi atau yang sering disebut dengan seni debus. Kesenian ini mempertunjukan kemampuan manusia yang kebal terhadap senjata tajam, air keras, dan sebagainya. Seni Debus lebih dikenal sebagai kesenian asli masyarakat Banten yang berkembang sejak abad ke-18. Kesenian ini bermula sejak abad ke-16 ketika masa pemerintahan Sultan Maulana Hasanuddin.

Adapun seni debus yang terdapat pada srtuktur penyajian dogdog kuda lumping panggeuing ati, yang dimana ada beberapa atraksi yang dilakukan oleh pawang kuda lumping kepada diri sendiri atau salah satu pemain.

\section{Struktur Gerak}

Dalam struktur gerak dogdog kuda lumping panggeuing ati tidak terdapat nama gerak ataupun penjelasan dari gerak tersebut. Karena, kesenian dogdog kuda lumping ini berbeda dengan kesenian kuda lumping pada umumnya, struktur gerak atau tarian yang ada dalam penyajian kesenian dogdog kuda lumping ini tidak beraturan. Hanya saja ada beberapa gerakan yang dilakukan oleh penari kuda lumping menyerupai gerakan kuda asli, seperti:

a. Penari kuda menaikan kaki kirinya dengan mengangkat kedua tangan sambil memegang kukudaan.

b. Kedua kaki jingjit dengan mengangkat kedua tangan yang sedang memegang kukudaan

c. Melangkahkan sebelah kaki yang diikuti kaki satunya dengan sedikit memiringkan dan bergerak sesuai dengan iringan musik

Akan tetapi struktur gerak ini di lakukan ketika penari kuda lumping mengalami intrance atau sedang kesurupan. Maka dari itu, jika membahas tentang gerak atau tarian dalam kesenian dogdog kuda lumping ini tidak terdapat nama gerak, pola lantai, atau penjelasan gerak yang detail seperti halnya stuktur gerak kuda lumping pada umumnya.

\section{Struktur Musik}

Dalam struktur musik yang digunakan pada kesenian dogdog kuda lumping panggeuing ati. Adapun lagu 
yang pertama dimainkan biasanya menggunakan lagu yang berjudul Rayakrayak. Lagu Rayak-rayak adalah lagu sunda yang biasa digunakan untuk pengiring Tari Jaipong, lagu ini dimainkan sampai penari kuda lumping dirasuki makhluk gaib yang menyerupai kuda oleh pawang sambil membacakan mantra yang tidak sembarang orang ketahui. Jika dalam istilah Sunda biasanya disebut nyambat berasal dari kata sambat yang berarti memanggil makhluk kasat mata.

Setelah itu lagu iringan ketika pertunjukan berlangsung biasanya menggunakan lagu yang tidak asing didengar oleh masyarakat Jawa Barat khususnya Sunda. Lagu-lagu tersebut di mainkan secara medley atau tidak ada jeda perlagu karena, walaupun kuda lumping sedang dalam keadaan intrance atau kesurupan akan tetapi penari kuda memiliki tiga unsur dalam seni tari yaitu wiraga, wirasa dan wirama.

Dari ketiga unsur tari tersebut unsur satu dengan lainnya memiliki arti yang berbeda. Wiraga yang berarti raga atau tubuh. Dengan begitu, para penari mampu menguasai penampilan tiap gerakan tubuh. Selanjutnya ada wirasa yang berarti mengekspresikan perasaan yang bisa dilakukan melalui gerak atau tarian. Demikian juga ada wirama yang berarti ritme atau tempo. Para penari harus mampu menggerakkan tubuh sesuai dengan musik dan tempo. Maka dari itu menurut pawang kuda dalam wawancara penelitian menyampaikan bahwa, jika musik berhenti ketika penari kuda lumping dalam keadaan kesurupan, maka penari kuda lumping akan ngamuk tidak beraturan sehingga bisa membahayakan penonton. Biasanya, lagu yang dimainkan untuk mengiringi adalah lagu-lagu Sunda biasanya seperti, lagu Karatagan Pahlawan, Es lilin, Sabilulungan, Mobil Butut, Mojang Priangan dan lain sebagainya.
Dengan dukungan dari alat musik yang merupakan salah satu pendukung dalam pertunjukan, juga menjadikan salah satu daya tarik tersendiri bagi kesenian tersebut. Alat musik adalah salah satu media pengumpul masa dalam pertunjukan kesenian khususnya. Alat musik atau waditra yang digunakan dalam kesenian kuda lumping panggeuing ati juga berperan sebagai salah satu ciri khas dalam kesenian ini. Dalam setiap pertunjukannya kuda lumping ini menggunakan alat musik yang menjadi ciri khas kesenian kuda lumping panggeuing ati yaitu alat musik Dogdog. Alat musik dogdog terbagi menjadi 4 bagian, diantaranya ada Tilingtit, Panempas atau Tong, Brum atau Brung, dan Badublang.

Istilah dogdog merupakan peniruan bunyi dari suara waditra atau alat musik yang dimainkan dengan cara dipukul dengan menggunakan teknik canon yang dimainkan secara bersahut- sahutan. Maka dari itu istilah penamaan dogdog adalah hasil dari alat musik yang jika dibunyikan terdengar "Dug" atau "Dog."

4. Properti Kesenian Doogdog Kuda Lumping Panggeuing Ati

a. Kuda Tiruan terbuat dari anyaman bambu yang dibentuk menyerupai kuda sungguhan. Dengan penambahan aksesoris pada kuda tiruan diantaranya:

Rambut kuda

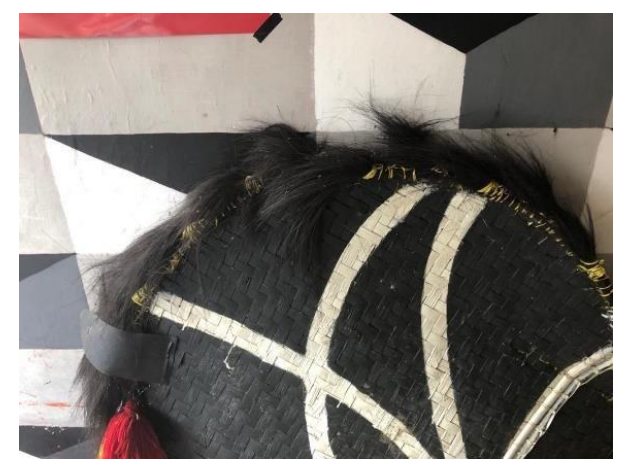

Gambar 1.

garis yang menyerupai muka kuda 


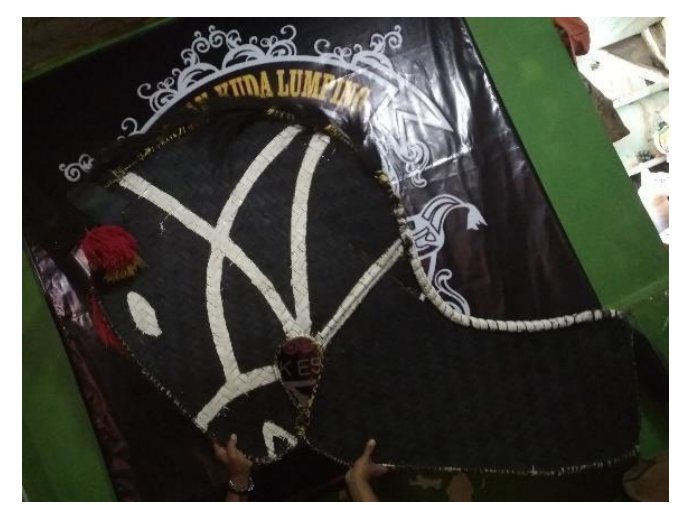

b. Kirincing (bel)

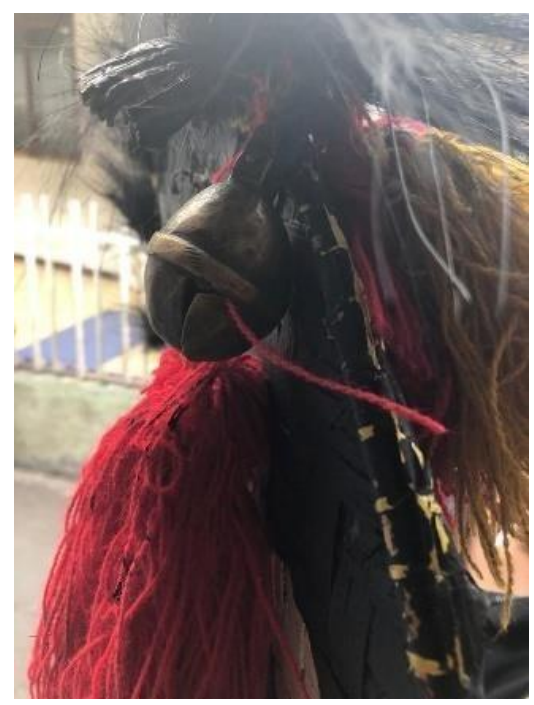

c. Kukumbul Kuda

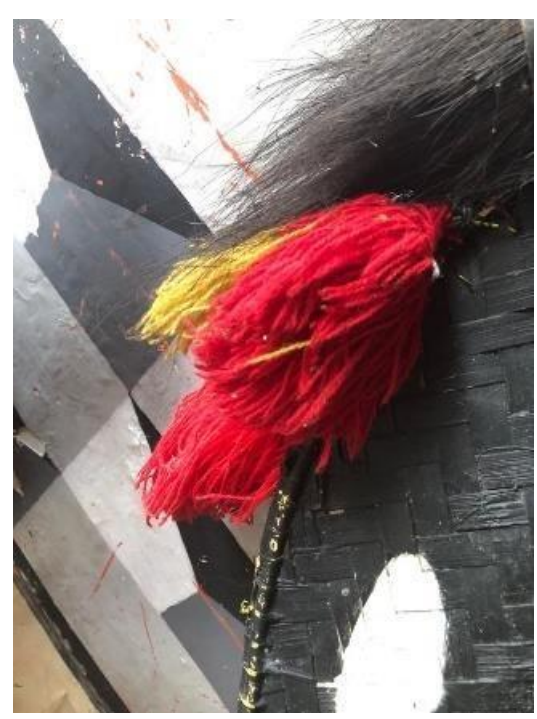

d. Kukumbul Angklung

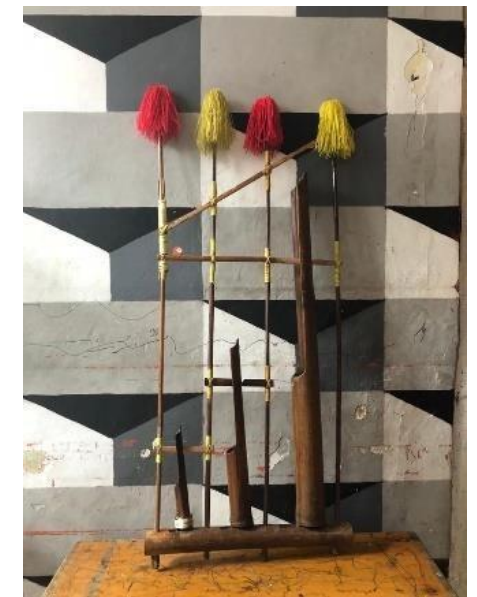

e. Buntut kuda

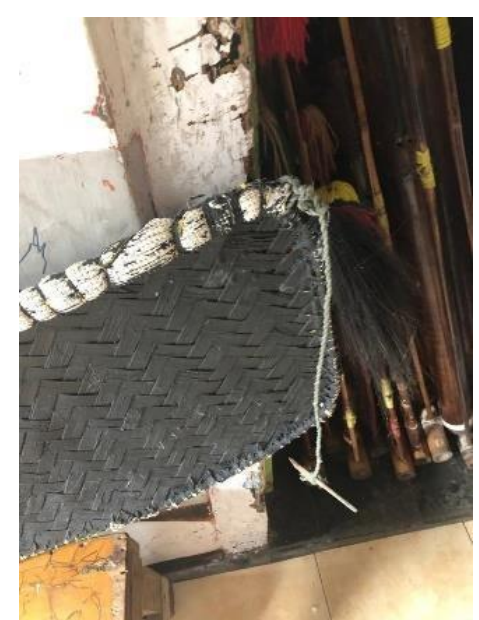

\section{Perbedaan}

Dari semua penjelasan diatas yang dibahas dalam penelitian ini adalah struktur penyajian antara kuda lumping pada umumnya dengan dogdog kuda lumping panggeuing ati. Didalam sturuktur penyajiannya terdapat hal pembeda, diantaranya dalam struktur gerak dan struktur musik.

Selain dari pada itu ada salah satu properti yang selalu digunakan penari kuda lumping pada umumnya, properti tersebut adalah Pecut kuda. Hingga, ada nama gerak tarian yang perlu menggunakan Pecut kuda. Beda halnya dengan dogdog kuda lumping panggeuing ati, pecut yang digunakan sebagai properti dalam setiap pertunjukan kuda lumping pada umumnya justru tidak digunakan pada kesenian dogdog kuda lumping panggeuing ati. 
a. Struktur Penyajian Kuda
Lumping Pada Umumnya
Dalam pembahasan diatas tampak terlihat perbedaan struktur penyajian yang digunakan kesenian kuda lumping pada umumnya dengan kesenian dogdog kuda lumping panggeuing ati.

\section{b. Struktur Gerak Kuda Lumping Pada Umumnya}

Struktur gerak yang terdapat pada kuda lumping pada umumnya meliputi ragam gerak, nama gerak, dan penjelasan gerak itu sendiri. Seperti yang terdapat pada jurnal seni tari yang ditulis oleh Sonia, Febrina (2019 : 219-225) yang mengungkapkan bahwa gerak Ndegar, Kebyak Jaran, Jangkah kanan kiri, jalan gejug maju, geyol mundur, maju adu bahu, dan selak'an jaran. Gerak pada tari kuda lumping masih sederhana, dan gerakkannya cenderung diulang-ulang. Estetika gerak tari kuda lumping muncul ketika penari menggerakkan seluruh elemen tubuh dari kepala, badan, tangan dan kaki. Keserasian antara elemen tubuh saat melakukan gerak tari menjadi suatu keindahan. Kesan gerak yang terdapat pada tari kuda Lumping yaitu energik, lincah, kuat terkadang gerakannya halus, dan juga lembut.

\section{c. Struktur Musik Kuda Lumping Pada Umumnya}

Stuktur musik yang digunakan oleh kesenian kuda lumping pada umumnya dalam bentuk dan struktur musik setiap daerah memiliki bentuk dan struktur musik yang berbeda-beda. Akan tetapi, dalam pertunjukan kuda lumping yang ada di daerah Jawa biasanya terdapat alat musik seperti, kendang, ketuk, kenong atau kempul (suspended gong), gong, dan sebuah slompret (seruling dengan bunyi melengking). Namun ada juga yang menggunakan alat musik yang lebih kompleks seperti menggunakan alat musik saron, gong, demung, dan tipung atau ketipung (kendang kecil), yang mana tadi disebutkan bahwasanya setiap daerah memiliki bentuk dan stuktur musik yang berbeda.

\section{Kesimpulan}

Terdapat makna atau arti pada alat musik dogdog, dalam satu alat dan ketika digabung menjadi kalimat pengingat bagi umat muslim kepada penciptanya. Menurut Kubarsah, Ubun (1994 : 77-80), mengungkapkan bahwa, pola tabuh dogdog memiliki arti. Arti tersebut terdapat pada alat musik tilingtit yang berarti gera indit gera indit, tong memiliki arti entong (jangan), suara dari waditra brung yang mengartikan embung, badubangplak memiliki arti gera prak yang ditujukan pada seruan atau perintah untuk melaksanakan ibadah shalat.

Jadi apabila digabungkan memiliki arti "gera indit gera indit, ulah emung ulah embung, prak gera gumamprak ka gusti Allah lamun geus asup waktuna shalat" atau dalam bahasa indonesianya yaitu "cepatlah berangkat jangan sampai tidak mau untuk melakukan shalat jika telah masuk tanda waktunya untuk shalat".

Lalu, terdapat perbedaan pada kuda lumping pada umumnya yang ada di pulau Jawa dengan dogdog kuda lumping panggeuing ati ini, terlihat dari struktur musik dan struktur geraknya. Seperti, dalam bentuk pola iringan musik, maupun dalam pola lantai gerak tariannya. Akan tetapi, salah satu properti yang digunakan kesenian tersebut sama-sama menggunakan kuda tiruan yang terbuat dari bambu yang dianyam menyerupai kuda sungguhan. 
Magelaran: Jurnal Pendidikan Seni, Vol 4. No. 2, Desember 2021, ISSN: 2620-8598

\section{Daftar Pustaka}

Djohan. (2009). Psikologi Musik. Yogyakarta: Penerbit Best Publisher.

Koentjaraningrat. (2004). Manusia dan Kebudayaan di Indonesia. Jakarta: Djambatan.

Koentjoroningrat, (1987). "sejarah teori antropologi". - Jakarta: Penerbit Universitas Indonesia (UI-press).

Koentjoroningrat. (1997). Pengantar Antropologi II, "pokok-pokok ethnografi". Penerbit PT RINEKA CIPTA

Kubarsah, Ubun (1994)."Waditra Mengenal Alat-Alat Kesenian Daerah Jawa Barat". Bandung: CV.Sampurna.

Nurul Zuriah, Dra, M.Si. (2005). Metodologi Penelitian Sosial dan Pendidikan, Teori-Aplikasi. Malang: Bumi Aksara.

Setyorini. (2013). Kesenian Kuda Lumping Di Tinjau Dari Perspektif. Jakarta : PT. Gramedia. Pustaka Utama.

Sugiyono. (2005). Memahami Penelitian Kualitatif. Bandung: CV. Alfabeta.

SUMARDJO, Jakob. (2016) Filsafat seni, edisi kesatu cetakan kedua. Bandung, ITB Press. Winarsih, Sri. (2010). “Mengenal Kesenian Nasional 12 Kuda Lumping”. Penerbit PT. BENGAWAN ILMU. 